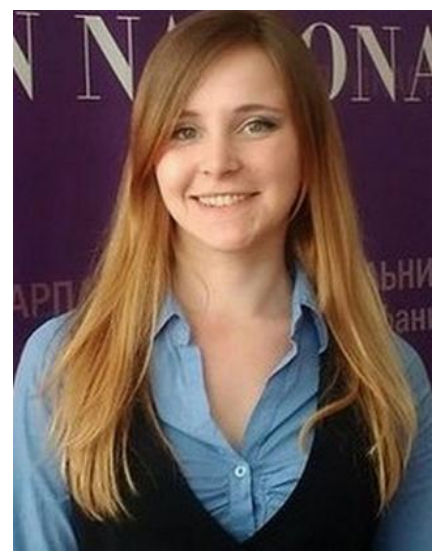

Лілія Бандура,

аспірант,

ДВНЗ «Прикарпатський національний університет

імені Василя Стефаника»

(м. Івано-Франківськ, Україна)

\author{
Liliia Bandura, \\ Postgraduate student, \\ Vasyl Stefanyk Precarpathian National University \\ (Ivano-Frankivsk, Ukraine) \\ galia_1963_lilia@ukr.net
}

\title{
СУТНІСТЬ ІННОВАЦІЙНИХ ТЕХНОЛОГІЙ НАВЧАННЯ У СУЧАСНІЙ НАУКОВІЙ ЛІТЕРАТУРІ
}

удк 371.134

Анотація. Автор розкриває актуальність питання інноваційних технологій навчання у науковій літературі. У статті проаналізовані інноваційні педагогічні технології як новостворені або вдосконалені педагогічні системи, що забезпечують високий рівень навчально-виховного процесу. У праці зазначено, що стан сучасної освіти залежить від їх ефективності та новаторства. Для того, щоб розвивати інноваційні технології та впроваджувати їх у навчальний процес, необхідно добре проаналізувати їхнє значення. Експериментальне дослідження, проведене нами в ході спілкування

з студентами 3-го курсу, дозволяє проаналізувати рівень усвідомлення ними основних понять їхньої майбутньої професійної діяльності. Детальний аналіз та порівняння тлумачень різних авторів даного поняття дозволяє краще пізнати його сутність та подати власне. Таку інформацію вважаємо корисною в розвитку освіти загалом та навчально-виховному процесі зокрема, оскільки вперше виведено цілісне значення поняття «інноваційні педагогічні технології». За концепцією «Нової української школи» прогресивний розвиток освіти можливий тільки за якісної підготовки майбутніх фахівців, що з використанням інноваційних педагогічний технологій матиме успішний результат. Метою статті $є$ розкрити сутність поняття «інноваційні педагогічні технології», використовуючи інформацію з найновіших публікацій з даної теми. Автор використав методи навчання: аналіз та узагальнення інформації з використаних джерел, порівняння та систематизація, експеримент та спостереження.

Ключові слова: інновація, технологія, педагогічна технологія, інноваційні педагогічні технології.

\section{THE ESSENCE OF INNOVATIVE TEACHING TECHNOLOGIES IN MODERN SCIENTIFIC LITERATURE}

Abstract. The author reveals the issue of innovative technology of teaching in scientific literature. The article analyzes innovative pedagogical technologies as newly created or improved pedagogical systems providing a high level of educational process. In the article it is not ed that the state of modern education depends on their efficiency and innovation.

In order to develop innovative technologies and implement them in the educational process, it is necessary to analyze their significance well. An experimental research, conducted by us during communication with students of the 3rd year of study, allows us to analyze the level of awareness of the main concepts of their future professional activities. Detailed analysis and comparison of interpretations of various authors of this concept allows you to better understand its essence and submit your own. A detailed analysis and comparison of interpretations of various authors of this concept makes it possible to better understand its essence and to present our own. We consider such information useful in the development of education in general and in the educational process in particular, since for the first time the integral meaning of the concept of «innovative pedagogical technologies» is derived. According to the concept of the "New Ukrainian School», the progressive development of education is possible only with the qualitative training of future specialists, which, with the use of innovative pedagogical technologies, will have a successful result.

The purpose of the article is to reveal the essence of the concept of «innovative pedagogical technologies», using information from the latest publications on this topic.

The author used such methods of teaching: analysis and synthesis of information from used literary sources, comparison and systematization, experiment and observation.

Keywords: Innovation, technology, pedagogical technology, innovative pedagogical technologies.

\section{ВСТУП}

Постановка проблеми. Суспільна потреба в ініціативних, креативних, всебічно і гармонійно розвинених, освічених фрахівцях, здатних до самовиховання та самонавчання, а також тих, хто вміє передавати свій досвід підростаючому поколінню, актуалізує соціальне замовлення на підготовку педагогів нової ери, здатних застосувати найновітніші технології педагогічної теорії та практики у процесі творчої самореалізації, роботі $з$ 
дітками. Про це наголошується в документах «Національній стратегії розвитку освіти 2012-2021рр.», концепції про «Нову українську школу» (2016).

Саме тому сьогодні заклади вищої освіти зіткнулись з питанням впровадження інноваційних технологій в освітній процес при підготовці майбутніх вчителів. У цьому контексті актуалізується розуміння поняття «інноваційні технології» для педагогічної науки і освіти. Глибокий аналіз сутності даного поняття дозволить краще зрозуміти, як і де можна застосовувати інновації, з'ясувати їх вплив на результати навчального процесу.

Аналіз останніх досліджень і публікацій. Питанням інноваційної спрямованості навчального процесу займається низка науковців: І. М. Дичківська, А. Нісімчук, О. В, Попова, О. П. Чубко та інші. Різноманітні аспекти професійної підготовки майбутніх вчителів у контексті інноваційних технологій висвітлювалися такими дослідниками, як О. М. Коберник, В. В. Любива, О.О.Харченко. Питання про розуміння «інноваційних педагогічних технологій» розкрито в працях О. С. Горащук, Г. М. Розлуцької, А. В. Шерудило та ін. Однак ця проблема потребує систематизації та узагальнення.

МЕТА І ЗАВДАННЯ ДОСЛІДЖЕННЯ - розкрити сутність поняття «інноваційні педагогічні технології» в сучасних наукових джерелах.

\section{МЕТОДИ ДОСЛІДЖЕННЯ}

Під час роботи над публікацією використовувалися такі методи дослідження: аналіз сучасних літературних та Інтернет джерел для вивчення і подальшого розуміння основних понять, аналіз та узагальнення науково-методичної та педагогічної літератури з проблеми інноватики, порівняннь тлумачень різних авторів одного поняття.

\section{РЕЗУЛЬТАТИ ДОСЛІДЖЕННЯ}

Перш ніж розглянути значення інноваційних педагогічних технологій, дамо визначення ключових понять: «інновація» та «педагогічна технологія».

Поняття «інновація» в перекладі з грецької мови означає «новизна» і тлумачиться як: «1) нововведення; 2) комплекс заходів, спрямованих на впровадження в економіку нової техніки, технологій, винаходів». Це поняття з'явилось уперше в зарубіжних дослідженнях XIX століття, коли сформувалась галузь інноватики - неологія (наука про нововведення), в рамках якої стали вивчатися закономірності технічних нововведень у сфері матеріального виробництва, це поняття знайшло своє відображення в економіці і стало характеризувати головний чинник стійкості розвитку країни [3, с. 352].

В соціолого-педагогічному словнику [7] термін «інновації» (від англ. - нововведення) тлумачиться як запровадження нових форм організації праці й управління, що охоплює не тільки окреме підприємство, а й їхню сукупність.

Як зазначає О. П. Чубко, слово інновація має латинське походження і в перекладі означає оновлення, зміну, введення нового. У педагогічній інтерпретації інновація означає нововведення, що поліпшує хід і результати навчально-виховного процесу [10, с. 2].

Поряд із цим терміном часто вживаються і терміни «новація» та «нововведення». Така багатогранність даного феномена, його неоднозначність, на наше переконання, спричинили відсутність єдиного підходу до його визначення. Для прикладу розглянемо кілька трактувань.

Вчені розрізняють поняття новація, або новий спосіб та інновація, нововведення. Новація - це сам засіб (новий метод, методика, технологія, програма тощо), а інновація - процес його освоєння. Одні науковці (В. Сластьонін, Л. Подимова та ін.) вважають інновації комплексним процесом створення, розповсюдження та використання нового практичного засобу в галузі техніки, технології, педагогіки, наукових досліджень [10, с. 2]. Інші (І. Підласий) заперечують, що інновації не можуть зводитись до створення засобів [10, с. 2].

Так, І. Підласий вважає, що інновації - це ідеї, і процеси, і засоби, і результати, взяті в якості якісного вдосконалення педагогічної системи. Розбіжності у тлумаченні поняття спричинені неоднаковим баченням їх авторами сутнісного ядра, а також радикальності нововведень [10, с. 2].

О. Листопад виокремлює такі значення терміну «інновація»: фрорма організації інноваційної діяльності; сукупність нових професійних дій педагога; зміни в освітній практиці; процес створення, розповсюдження та використання нового практичного засобу; новизна, що змінює результати освітнього процесу; кінцевий результат інноваційної діяльності; реалізоване нововведення; комплексний процес створення; оновлення; кінцевий результат творчої діяльності» [6, с. 50].

Погоджуючись із В. Загвязинським, О. Попова вживає терміни «нововведення» й «інновація» як синонімічні та трактує ці поняття як «цілеспрямовану зміну, що вносить у середовище нові стабільні елементи (нововведення), які спричиняють перехід системи від одного стану в інший». На думку науковця, нововведення або інновація - це комплексний процес створення, використання і поширення нового практичного засобу для нової суспільної потреби, що викликає певні зміни у тій сфері, де відбувається його застосування. Л. Базиль пропонує розглядати інновацію як «кінцевий результат творчої праці, що одержав реалізацію у вигляді нової чи удосконаленої продукції, нового чи удосконаленого технологічного процесу» [1, с. 11].

Ми розглядаємо поняття «нововведення» та «інновація» як тотожні. Інновація, на нашу думку, - це якісна зміна, яка модернізує будь-який процес, роблячи його цікавішим та водночас простішим для розуміння і використання.

Далі розглянемо сутність поняття «педагогічна технологія», яке представники освітнього процесу почали все частіше вживати сьогодні. Нині їх існує понад триста. Залежно від сфрери діяльності та розуміння стуктури цього поняття існують наступні його визначення. 
Я. Крупський, В. Михалевич визначають «технологію» як: 1) мистецтво, майстерність, уміння й сукупність методів обробки; 2) сукупність прийомів, застосовуваних у будь-якій справі; 3) сукупність способів обробки чи переробки матеріалів, інформації, виготовлення виробів, проведення різних виробничих операцій, надання послуг тощо [5, с. 71].

На думку А. В. Шерудило, педагогічні технології - це складні системи прийомів і методик, об'єднаних пріоритетними загальноосвітніми цілями, концептуально взаємопов'язаними між собою завданнями і змістом, формами і методами організації навчально-виховного процесу, де кожна позиція накладає відбиток на всіх інших, що і створює в результаті певну сукупність умов для розвитку вихованців [11, с. 444].

Основні визначення педагогічних технологій подаємо у таблиці 1.

Таблиця 1

Розуміння вченими сутності поняття «педагогічна технологія»

\begin{tabular}{|l|l|}
\hline \multicolumn{1}{|c|}{ Автор } & \multicolumn{1}{c|}{ Сутість поняття } \\
\hline С. О. Сисоєва & $\begin{array}{l}\text { Педагогічна технологія - це створена адекватно до потреб і можливостей особистості і } \\
\text { суспільства теоретично обгрунтована навчально-виховна система соціалізації, особистіс- } \\
\text { ного і професійного розвитку і саморозвитку людини в освітній установі, яка, внаслідок } \\
\text { упорядкованих професійних дій педагога при оптимальності ресурсів і зусиль усіх учасни- } \\
\text { ків освітнього процесу, гарантовано забезпечує ефективну реалізацію свідомо визначеної } \\
\text { освітньої мети та можливість оптимального відтворення процесу на рівні, який відповідає } \\
\text { рівню педагогічної майстерності педагога [8, с. 122]. }\end{array}$ \\
\hline Ю. Хайчіна & $\begin{array}{l}\text { Педагогічна технологія - своєрідна конкретизація методики, проект певної педагогічної } \\
\text { системи, що реалізується на практиці; змістова техніка реалізації навчально-виховного } \\
\text { процесу; закономірна педагогічна діяльність, яка реалізує науково-обґрунтований проект } \\
\text { навчально-виховного процесу і має вищий рівень ефективності, надійності, гарантованого } \\
\text { результату, ніж традиційні методики навчання й виховання [9]. }\end{array}$ \\
\hline
\end{tabular}

Як бачимо з вищеподаної таблиці, спільними для даних визначень $є$ те, що педагогічна технологія позитивно впливає на навчально-виховний процес, сприяє підвищенню його ефективності та саморозвитку. Проте спостерігаємо і відмінне, а саме те, що в першому визначенні (за С. О. Сисоєвою) це система, яка спрямовує свою професійну дію на особистість, її соціалізацію, розвиток під керівництвом педагога; в другому визначенні (за Ю. Харченко) «педагогічна технологія» характеризується як вузьке поняття: техніка, спосіб, метод, за допомогою якого навчально-виховний процес має високий рівень продуктивності у порівнянні з традиційними методами навчання та виховання.

За визначенням ЮНЕСКО, педагогічна технологія - це, в загальному розумінні, системний метод створення, застосування й визначення всього процесу навчання і засвоєння знань, з урахуванням технічних і людських ресурсів та їх взаємодії, який ставить своїм завданням оптимізацію освіти [2, с. 278].

Ми погоджуємось з даним визначенням про те, що це конкретизація певної педагогічної методики, спосіб ведення навчального процесу, який бере до уваги впливи всіх чинників на його перебіг, а також вважаємо, що це поняття настільки багатогранне, що охоплює і узагальнює суть всіх визначень різних авторів.

Отже, ми проаналізували значення понять «інновація» та «педагогічна технологія», проте термін «інноваційні технології», який поєднує в собі визначення двох понять, досі $€$ не визначеним.

Аналізуючи вищезгадане, робимо висновки про те, що «інноваційні педагогічні технології» в широкому значенні

- це сучасна педагогічна система, яка забезпечує високий рівень освітнього-виховного процесу; у вузькому значенні - це якісний спосіб організації навчального процесу, що спрощує його та робить водночас ефективнішим.

Основними критеріями «інноваційних педагогічних технологій», на нашу думку, є: а)

новизна ( виходить із значення та походження слова «інновація»);

б) ефективність (повинні приносити позитивні результати в будь-якій діяльності загалом та в освітньому процесі зокрема);

в) креативність (надають можливість творчого розвитку під час застосування, фрормують нове бачення та підходи до використання);

г) раціональність (забезпечують найефективніші результати за найменших затрат сил, розуму та часу);

ґ) пристосованість (повинні бути доступними у використанні в будь-яких умовах, з будь-якою аудиторією, за будьяких обставин).

Як показало вищевикладене, трактування поняття «педагогічна технологія» $є$ різноманітним. Для одних учених це цілісна педагогічна система, що несе позитивні зміни в освіту. Інші розуміють її як конкретизацію методики, тобто спосіб, шлях покращення навчально-виховного процесу

Нами проведено опитування серед студентів 3-х курсів Прикарпатського національного університету імені Василя Стефраника про розуміння ними поняття «інноваційних технологій навчання» як педагогічної системи чи як конкретного способу, шляху покращення навчального-виховного процесу . Дані опитування наведено в діаграмі на рис.1.

Ми дійшли висновку, що не всі студенти достатньо ознайомлені із суттю цього терміну. 3 25 студентів тільки 13 відповіли, що це все-таки конкретний спосіб, шлях, метод, а 12 - що це педагогічна система. 3 цього робимо висновок, що справді, як зазначили С. Сисоєва та Ю. Хайчіна, це поняття дуже багатогранне, і ще немає чіткої межі між відтінками значення. Тому наше дослідження має сенс, оскільки ми дали визначення поняття, що, на нашу думку, найкраще розкриває його зміст. Проте дана проблема потребує більш детального розгляду. 
Оцінка розуміння студентами значення поняття "інноваційні технології навчання"

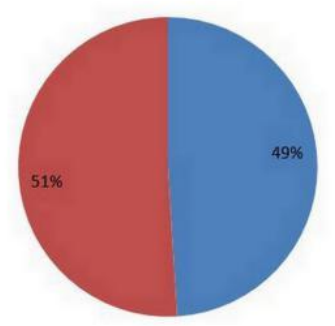

- Педагогічна систем

- Спосіб, шлях

\section{ВИСНОВКИ ДОСЛІДЖЕНЬ \\ TA \\ ПЕРСПЕКТИВИ \\ ПОДАЛЬШИх}

Отже, інноваційні педагогічні технології на сучасному етапі розвитку освіти $€$ феноменом, що швидко проникає в усі педагогічні системи, позитивно на них впливає і $€$ незворотним процесом, що має здатність постійно розвиватися. У сучасних літературних джерелах часто зустрічаємося з цим поняттям, оскільки педагогічний процес має здатність постійно розвиватися. Трактуємо «інноваційні педагогічні технології» як ефективні нововведення, що стосуються організації освітнього процесу

загаломтаіснуютьякокреміметоди(увузькомузначенні)реалізації окремої його частини. Наше узагальнення може бути використане як учителями, так і викладачами вищих навчальних закладів при плануванні заняття, написанні методичних розробок для студентів тощо.

Рис. 1. Результати опитування студентів щодо розуміння ними поняття «інноваційні педагогічні технології»

\section{СПИСОК ВИКОРИСТАНИХ ДЖЕРЕЛ}

[1] Гавриляк І. С. Ідеї становлення освітніх інновацій в сучасній Україні. Молодий вчений. 2018. № 3.1 (55.1). С. 23 - 26

[2] Гончаренко С. Український педагогічний словник К., 1997. 376 с.

[3] Горащук О. С. Сутність поняття “інноваційні педагогічні технологіï” URL: http://ps.stateuniversity.ks.ua/file/issue 49/81.pdf

[4] Нова українська школа. 2016. URL: https://www.kmu.gov.ua/storage/app/media/reforms/ukrainska-shkola-compressed.pdf

[5] Крупський Я. В., Михалевич В.М. Тлумачний словник з інформаційно-педагогічних технологій. Вінниця. 2010.72 с.

[6] Листопад О. В. Інноваційний розвиток освіти й освітні інновації. Понятійно-термінологічний аналіз проблеми. Інновації у професійно-педагогічній підготовці майбутнього вчителя: методологічні, змістові та методичні аспекти: монографія. Суми: Видавництво “МакДен”, 2011. С. 43-60.

[7] Радул В. В. Соціолого-педагогічний словник. К. : ЕксОб, 2004. 304 с.

[8] Розлуцька Г. М. Інноваційні технології в педагогічному процесі вищої школи. Педагогіка, соціальна робота. 2011. С. 121 - 123.

[9] Хайчіна Ю. Словник педагогічних термінів від К до Я .URL: ://www.model.poltava.ua/index.php?option=com_content\& view=article\&id=579:2012-12-18-17-32-37\&catid=102:2012-11-21-09-00-45\&ltemid =427

[10]Чубко О.П. Інноваційні технології навчання в контексті педагогічної підготовки майбутнього вчителя. URL: https://www. google.com.ua/search?biw=1366\&bih=618\&ei=4Lj5W -TsHluqswHkxrygCg\&q

[11] Шерудило А. В. Сутність та класифікація інноваційних технологій у дитячих закладах оздоровлення та відпочинку. Збірник наукових праць. 2015. Випуск 18. С. $442-448$.

\section{REFERENCES (TRANSLATED AND TRANSLITERATED)}

[1] Ghavryljak I. S. Ideji stanovlennja osvitnikh innovacij v suchasnij Ukrajini (Ideas of formation of educational innovations in modern Ukraine). Molodyj vchenyj. 2018. № 3.1 (55.1). S. 23 - 26. (in Ukrainian)

[2] Ghoncharenko S. Ukrajinsjkyj pedaghoghichnyj slovnyk (Ukrainian Pedagogical Dictionary). K., 1997. 376 s. ( In Ukrainian)

[3] Ghorashhuk O. S. Sutnistj ponjattja "innovacijni pedaghoghichni tekhnologhij" (The essence of the concept of "innovative pedagogical technologies"). URL: http://ps.stateuniversity.ks.ua/file/issue_49/81.pdf (in Ukrainian)

[4] Nova ukrajinsjka shkola (New ukrainian school). 2016. URL: https://www.kmu.gov.ua/storage/app/media/reforms/ukrainska-shkolacompressed.pdf (in Ukrainian)

[5] Krupsjkyj Ja. V., Mykhalevych V.M. Tlumachnyj slovnyk z informacijno-pedaghoghichnykh tekhnologhij (Interpretative dictionary of informational and pedagogical technologies). Vinnycja. 2010. 72 s. (in Ukrainian)

[6] Lystopad O. V. Innovacijnyj rozvytok osvity j osvitni innovaciji. Ponjatijno-terminologhichnyj analiz problem (Innovative development of education and educational innovations. Conceptual and terminological analysis of the problem). Innovaciji u profesijno-pedaghoghichnij pidghotovci majbutnjogho vchytelja: metodologhichni, zmistovi ta metodychni aspekty: monoghrafija. Sumy: Vydavnyctvo "MakDen", 2011. S. 43-60. (in Ukrainian)

[7] Radul V. V. Sociologho-pedaghoghichnyj slovnyk (Sociological and Pedagogical Dictionary). K. : EksOb, 2004. 304 s. (in Ukrainian)

[8] Rozlucjka Gh. M. Innovacijni tekhnologhiji v pedaghoghichnomu procesi vyshhoji shkoly (Innovative technologies in the pedagogical process of higher education). Pedaghoghika, socialjna robota. 2011. S. 121- 123. (in Ukrainian)

[9] Khajchina Ju. Slovnyk pedaghoghichnykh terminiv vid $\mathrm{K}$ do Ja (Dictionary of pedagogical terms from $\mathrm{K}$ to $\mathrm{Y}$ ). URL: ://www. model.poltava.ua/index.php?option=com_content\&view=article\&id=579:2012-12-18-17-32-37\&catid=102:2012-11-21-09-0045\&ltemid=427 (in Ukrainian)

[10] Chubko O.P. Innovacijni tekhnologhiji navchannja v konteksti pedaghoghichnoji pidghotovky majbutnjogho vchytelja (Innovative learning technologies in the context of teacher training for future teachers). URL: https://www.google.com.ua/ search?biw=1366\&bih=618\&ei=4Lj5W-TsHluqswHkxrygCg\&q (in Ukrainian)

[11] Sherudylo A. V. Sutnistj ta klasyfikacija innovacijnykh tekhnologhij u dytjachykh zakladakh ozdorovlennja ta vidpochynku (The essence and classification of innovative technologies in children's recreation and recreation facilities). Zbirnyk naukovykh pracj. 2015. Vypusk 18. S. $442-448$. (in Ukrainian) 